\title{
Students Humorous Learning Styles in the Learning of Malay Language Literature Components
}

\author{
Sii Kiong Ming \& Mohd Razimi bin Husin \\ Faculty of Education \& Human Development, \\ University Pendidikan Sultan Idris, Perak Malaysia \\ Email: razimi@fpm.upsi.edu.my \\ DOI: https://doi.org/10.37134/jcit.vol10.5.2020
}

Cite this paper (APA): Husin, M. R., \& Sii, K. M. (2020). Students Humorous Learning Styles in the Learning of Malay Language Literature Components. Journal of Contemporary Issues and Thought, 10, 46-53. https://doi.org/10.37134/jcit.vol10.5.2020

\begin{abstract}
This study aims to identify the effects of the types of students humorous learning style as predictive factors in learning Malay Language Literature Components. The study also aims to identify the different students humorous learning styles in Malay Language Literature Components based on gender. The Perceptual Learning Style Preference Questionnaire was used and adapted from Reid (1984). The sample selection was conducted using a random sampling method. The study sample consists of 30 students of a total of 17 male students and 13 female students at a high school in the district of Bintulu, Sarawak. The results of the study were analyzed using inference statistics involving multiple linear regression and t-test. The results show that there were significant differences in terms of the types of students humorous learning styles as predictive factors in learning Malay Language Literature Components. The results also showed that there was no significant difference in terms of students humorous learning styles in Malay Language Literature Components based on gender. The implications of this study suggest that it can serve as a reference to improve the professionalism of school teachers and bridge the humor and learning styles of students in the teaching and learning of Malay language literature components.
\end{abstract}

Keywords: Students Humorous; Learning Styles; Learning; Malay Language; Literature Components

\section{Introduction}

The Ministry of Education through the National Education Development Plan 2013-2025 emphasized student aspirations through teaching and learning to enhance the quality of student achievement. Today, a healthy and enjoyable learning environment has been noted by the Ministry of Education Malaysia. The Ministry of Education Malaysia has introduced a fun learning concept by incorporating elements of humor in teaching and learning to create an effective learning environment. Furthermore, humor has always been one of the most important elements in determining the effectiveness of a teacher's teaching.

Humor is a very important element of interest in attracting students to receive information that the teacher presents in the classroom. Students will also be entertained because the element of humor can make them laugh out of humor. In the context of education, the use of humor in the classroom not only positively affects student learning, it also enhances the motivation and confidence of students and teachers in the communication process (Gilliam, 2019). 
The application of the element of humor in the context of contemporary teaching and learning is an important entity to influence students' interest in a subject that is proven to be an agent of change, namely, changing from gloomy to more interactive (Junis \& Synthesis, 2019). Based on this fact, this element of humor can enhance students' confidence to feel comfortable in the classroom and thus stimulate student learning. As such, the Ministry of Education Malaysia emphasizes on the element of humor through the concept of fun learning. Meanwhile, humor plays a role in improving the classroom climate and enhancing students' learning (Jihene, Rejeb, \& Malefan, 2020).

Recently, the field of neurology and cognitive psychology has revealed how brain structures and functions operate in concert with emotion-stimulated emotions to produce effective teaching and learning processes (Amran, Rahman, \& Letters, 2017). In addition, Bakar and Kumar (2019) also say that teachers need to be creative and knowledgeable in order to implement meaningful teaching. This is important and influences teachers' understanding to ensure that teachers understand how students learn and understand students' feelings.

In addition, some studies revealed that educators also face problems in achieving the effectiveness of the teaching process because it does not fully understand a person's interests and learning styles of students in learning Malay Language Literature Components. For example, Ahmad and Jinggan (2015) argue that teachers' failure to identify appropriate learning styles will affect students lack of interest in learning, while Mahamod, Ghani and Mohamad (2016) argue that student learning styles need to be identified to reinforce the effectiveness of their learning.

In this context, humor clearly links the ability of a student's right brain and left brain to work simultaneously by evaluating and acquiring learning information in a relaxed but meaningful manner so that effective learning can be generated using the two brains to the maximum. According to Abdullah, Aziz and Mohamed (2007), the ability to apply humor and humanistic allows students with different learning styles to learn Malay with a more relaxed, entertained, and enjoy the atmosphere that is conducive to absorb knowledge.

\section{Literature Review}

Reduwan (2011) has identified six styles of humor in the Malay language, the style of teaching through visual, kinesthetic, tactile, auditory, groups and individuals. A total of 150 samples from the control group and 20 samples from the experimental group were included in this study. This is evidenced by the fact that the qualitative data was obtained through observation by taking into account the emotions and feelings of the student's jokes during the mini-drama and watching the movie. Quantitative data about student learning styles of humor are also reinforcing these findings indicate that there is a strong relationship between students' learning styles with the application of humor as a stimulant in the Malay language learning situation.

The study of Bhattacharyya and Sarip (2014) was conducted in Malaysia to identify the types of learning styles and their impact on higher education students. This study was conducted on 73 students by testing their perceptions of their learning style based on the VAK model. The results show that students are more likely to adopt a visual learning style that involves using pictures, writing, making notes and viewing maps or diagrams in the learning process. The study also concludes that each student has his or her own learning style in all three types of styles introduced by the VAK model. The results also indicate that there is a difference between male and female students in the tendency to choose the right learning style. Overall, the results of this study prove that male students prefer visual learning style over female students. 
The study of Sukor and Shah (2016) aimed at identifying differences in the style of humor behavior based on demographic factors, including gender factors. A total of 108 postgraduate students at the Faculty of Management, Universiti Teknologi Malaysia (UTM), were sampled. The measuring instrument used to measure humor behavior is the Humor Styles Questionnaire (HSQ). The findings show that there is a significant difference in students' sense of humor based on gender factors, which means that boys are more likely to use humor to excite, relieve and entertain themselves to create a more cheerful and positive learning environment.

In addition, the study conducted by Pourhossein (2012) was to study the effect of VAK learning style on student learning in English. This Iran-based study was conducted on 100 students. Overall, the results show that most of the respondents in the study adopted a visual learning style compared to the auditory learning style and kinesthetic learning style.

However, there are also findings of the study which are contrary to the findings previously obtained. This can be seen through the study of Gholami and Bagheri (2013). This study involved 102 randomly selected students at Boushehr Islamic Azad University in Iran. The findings of this study show that the VAK learning model does not make a significant difference in student learning based on gender factors.

\section{Application Model}

In this study, the researchers used the VAK model to identify the learning styles of students in selected schools. According to Gholami and Bagheri (2013), VAK learning styles models were introduced by psychologists such as Fernald, Keller, Orton, Gillingham, Stillman and Montessori in the early 1920s. These models discussed three types of learning styles that students often use in their learning, which is a visual, auditory and kinesthetic learning style.

First, the visual learning style. In this learning style, students learn better by looking at a text word in a book, on a blackboard or on a computer display. They are better able to remember and understand the instructions and explanations by reading the verse or text.

Second, the style of auditory learning. In this style of learning, "auditory" students learn by listening to spoken words as well as spoken instructions. They can remember descriptions through strong readings or move their lips while reading, especially when learning something new. Students can improve their memory by listening to audio recordings again, teaching other students, and talking with teachers.

Third, kinesthetic learning styles. In this learning style, "kinesthetic" students learn well through experience and participate physically in classroom activities. They can remember things well when they try their hands-on activities.

In conclusion, the learning style based on this VAK model focuses on three types of learning, namely visual, auditory and kinesthetic. This model shows that each learning process will be influenced by these three styles. There are students who are only focused on one style, but there are also students who incorporate all three of these VAK model styles into their learning process.

\section{Research Objective}

The objective of this research is to:

1. Identify the effects of the types of students humorous learning styles as predictive factors in learning Malay Language Literature Components.

2. Identify the different students humorous learning styles in Malay Language Literature Components based on gender. 


\section{Methodology and Data Collection}

In this study, the methodology of the study used is a quantitative study. The study sample consisted of 30 students at a high school in Bintulu District, Sarawak. The researcher conducted item analysis on the Literary Components questions in paper 2 [Questions 2 (b), 2 (c) and 2 (d)] among the identified populations. Therefore, all the study subjects among these selected students are based on achievement in the aspect of the Literary Components that excelled in the internal examination of the school. This indicates that the sampling was aimed at these students to fully meet all the criteria, characteristics and information as required by the researchers in this study. Subsequently, the collected data are used to reject or support the hypothesis of the study so that it can be generalized by analyzing and interpreting the data obtained from the students. The Perceptual Learning Style Preference Questionnaire was used and adapted from Reid (1984). A 5point Likert Scale was provided in the questionnaire to obtain information on student learning styles. The quantitative data in this study were analyzed using IBM SPSS version 25 software statistically inference.

\section{Pilot Study}

The pilot study was also conducted by the researcher to ensure the validity and reliability of the instrument obtained. The researcher validated the instrument with the evaluation of three expert evaluators in educational psychology. Therefore, the researcher has conducted a pilot study to obtain instrument reliability by distributing questionnaires to 30 students who are not actual samples but have the same characteristics, characteristics, and character or similarities as the actual sample. The results of the pilot study can be found in Table 1.

Table 1: Correlation and Cronbach Alpha in Pilot Test

\begin{tabular}{ccccc}
\hline Item & $\begin{array}{c}\text { Inter-item } \\
\text { Correlation }\end{array}$ & $\begin{array}{c}\text { Corrected Item- } \\
\text { Total Correction }\end{array}$ & $\begin{array}{c}\text { Cronbach's Alpha if } \\
\text { Item Deleted }\end{array}$ & $\begin{array}{c}\text { Cronbach } \\
\text { Alpha }\end{array}$ \\
\hline 1 & 1.000 & 0.743 & 0.927 & 0.934 \\
2 & 0.560 & 0.633 & 0.931 & \\
3 & 0.728 & 0.900 & 0.923 & \\
4 & 0.576 & 0.755 & 0.927 & \\
5 & 0.568 & 0.703 & 0.929 & \\
6 & 0.553 & 0.720 & 0.928 & \\
7 & 0.353 & 0.511 & 0.933 & \\
8 & 0.320 & 0.486 & 0.934 & \\
9 & 0.560 & 0.633 & 0.927 & \\
10 & 0.759 & 0.828 & 0.923 & \\
11 & 0.728 & 0.900 & 0.927 & \\
12 & 0.576 & 0.755 & 0.927 & \\
13 & 0.576 & 0.755 & 0.927 & \\
14 & 0.402 & 0.492 & 0.934 & \\
15 & 0.411 & 0.519 & 0.934 & \\
\hline
\end{tabular}


Based on Table 1, the constructs had an inter-item correlation score with a score of 0.320 to 1,000 while the corrected item-total correction ranged from 0.486 to 0.900 . The coefficient alpha is 0.934 . The overall coefficient of alpha is $\alpha=0.934(0.934 \times 100)=93.4$ percent. This shows that 93.4 percent of the reliability of items in the questionnaire is consistent. This also means that 93.4 percent of the degree of reliability of the sample on the questionnaire was answered. The value of inter-item correlation and corrected item-total correction is greater than 0.30 . This indicates that all items in this construct also have a high validity value. If viewed through alpha values, if items are deleted, this column indicates that all items have an ideal coefficient correlation coefficient value of 0.70 . Therefore, none of the items dropped from this instrument and this instrument is reliable and is used for its in-depth study in measuring the learning style of student humor.

\section{Results}

Inferential statistics involves multiple linear regression and t-test are used to answer two hypotheses in this study. Based on Table 2, the first null hypothesis tested with multiple regression tests to answer the first study question is as follows:

$\mathrm{H}_{01}=$ There was no effect of the types of students humorous learning style as predictive factors in learning Malay Language Literature Components.

Table 2 shows the visual factors, factors audio and kinesthetic factor is a predictor or contributors to the students humorous learning style in learning Malay Language Literature Components.

Table 2: Multiple Regression Linear

\begin{tabular}{lcccccc}
\hline Type Style & $\mathrm{B}$ & $\begin{array}{c}\text { Beta } \\
(\beta)\end{array}$ & $\begin{array}{c}\text { Value } \\
-\mathrm{t}\end{array}$ & Sig. & $\mathrm{R}^{2}$ & $\begin{array}{c}\text { Contribution } \\
0.932 \times 100 \%\end{array}$ \\
\hline Visual & 1.167 & 0.966 & 19.651 & 0.000 & 0.932 & 93.2 \\
Audio & 1.014 & 0.359 & 5.653 & 0.000 & 0.037 & 3.7 \\
& & & & & 0.969 & \\
Kinesthetic & 1.031 & 0.308 & 13.170 & 0.000 & 0.027 & 2.7 \\
& & & & & 0.996 & \\
\hline
\end{tabular}

Researchers have determined whether there is multicollinearity in the data displayed before data analysis is performed. This was detected by the researcher with reference to the correlation relationship between the independent variable and the dependent variable having a correlation value of less than $r=0.7$ as shown in Table 3 .

Table 3: Excluded Variables ${ }^{\mathrm{a}}$

\begin{tabular}{cccccccc}
\hline Type Style & Beta In & $\mathrm{t}$ & Sig. & \multicolumn{2}{c}{$\begin{array}{c}\text { Partial } \\
\text { Correlation }\end{array}$} & & \multicolumn{2}{c}{ Collinearity Statics } \\
\hline 1 & & & & & & Tolerance & VIF \\
\cline { 7 - 8 } & $\mathrm{V}$ & $.359^{\mathrm{b}}$ & 5.653 & 0.000 & .736 & .285 & 3.508 \\
& $\mathrm{~A}$ & $.298^{\mathrm{b}}$ & 4.014 & 0.000 & .611 & .285 & 3.514 \\
& $\mathrm{~K}$ & $.308^{\mathrm{c}}$ & 13.170 & 0.000 & .933 & .284 & 3.516 \\
\hline
\end{tabular}

Based on Table 3, researchers also refer to this multicollinearity problem by looking at the values of Tolerence and VIF (Variance Inflation Factor). Since the Tolerence value is not less than 0.10, this indicates that there is no multicollinearity problem because the partial correlation between 
the variables is high. In addition, the VIF value was less than 10 (VIF $<10)$, indicating that there was no multicollinearity between the variables. Overall, Table 3 shows Tolerance value $=0.285$ ( $>$ $0.10)$ and VIF value $=3.508(<10)$. This indicates that there are no multicollinearity problems between the variables.

In addition, the researcher has also referred to data normalization through the normalized PP Plot of Regression Standardized Residual and Scatterplot. The P-P plot in this study shows that all points lie within or near the diagonal line straight and reasonably from left to right with no deviation from the normal line. This can be seen through Figure 1 as follows:

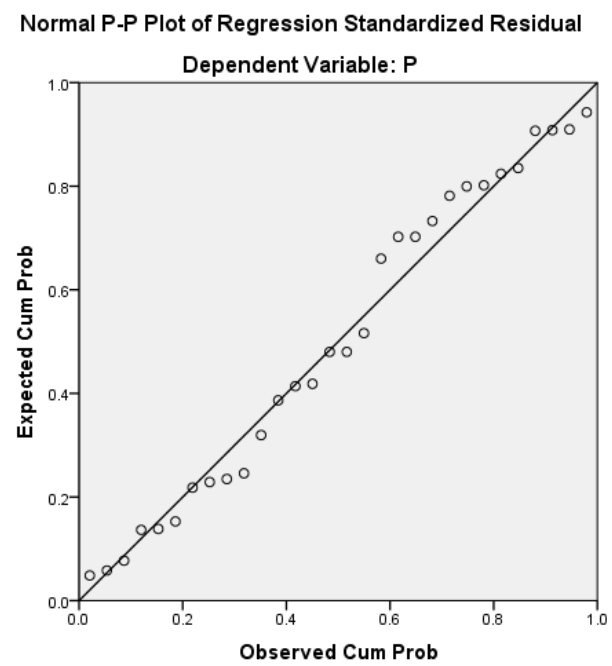

Figure 1: P-P Plot of Regression Standardized Residual of Students Humorous Learning Style

As such, it can be stated that the findings of this study indicate the level of contributions highest on learning styles of humor in learning the components Literary Malay language came from the learning style of visual humor $=93.2$ percent (contribution), learning style audio $=3.7$ percent (small contribution), and kinesthetic learning style $=2.7$ percent (small contribution). In other words, the learning style of student humor is measured by the visual learning style among the students.

Therefore, the null hypothesis stating that there is no effect of the types of students humorous learning styles as predictive factors in learning Malay Language Literature Component is rejected. This is in line with some previous studies showing that students are more likely to adopt visual learning styles than auditory and kinesthetic learning styles (Bhattacharyya \& Sarip, 2014; Pourhossein, 2012; Reduwan, Yusuf, \& Hasim, 2016). In fact, this finding is also in line with Reduwan study (2011) showed that there are power relationships between learning styles of humor is visual, audio and kinesthetic application of humor as a stimulant in the Malay language learning situation.

The second null hypothesis tested by the t-test to answer the second study question is as follows:

$\mathrm{H}_{02}=$ There were no significant differences in the students humorous learning styles in Malay Language Literature Components based on gender. 
Table 3: Students Humorous Learning Style Based On Gender Factors

\begin{tabular}{lccccc}
\hline Gender & $\mathrm{n}$ & Mean & $\begin{array}{c}\text { Standard } \\
\text { Deviation }\end{array}$ & $\mathrm{t}$ & Sig.(2-tailed) \\
\hline Male & 17 & 28.17 & 7.06 & .511 & .614 \\
Female & 13 & 26.77 & 8.00 & & \\
\hline
\end{tabular}

Table 3 shows the results of analysis to answer the hypothesis of this study. The study found that this hypothesis should be accepted. Based on the analysis, it is found that there are no significant differences in the students humorous learning styles in Malay Language Literature Components based on gender.

Based on Table 3, $\mathrm{t}$-values for the comparison of learning styles of humor for boys and girls were found to be $t=0.511$ and significant $p=0.614$. This significance level was greater than 0.05 ( $p>0.05)$. Mean scores on the level of humor element performance for male and female students respectively were 28.17 and 26.77, respectively. Therefore, the second null hypothesis (H02) is accepted. This is in line with the findings of Gholami and Bagheri (2013) study that there is no significant difference between students' learning styles in the study based on gender factors.

\section{Conclusion and Recommendations}

In conclusion, the visual learning styles of humor are found to affect the achievement of Malay Language Literature Components in this study. The learning style of visual humor for students should be improved continuously. This is because the implementation of the teaching and learning of Malay Language Literature Components corresponding to the learning style of humor to work to improve student interest in learning Malay Language Literature Components with a more effective and efficient. In this regard, the findings of this study are intended to serve as a guide to all teachers, the Curriculum Development Center, the Ministry of Education and others in providing an effective and effective way to teach the aspects of student humor in the teaching and learning process of Literary Components. However, further research to explore other aspects that influence the achievement Components Literature Malay language is proposed to obtain a comprehensive picture with regard to the factors that affect achievement Components Literature Malay language in line with the curriculum of the Malay language and the transformation of the national education policy nationally and globally.

\section{References}

Abdullah, A.G., Aziz, A.R.A., \& Mohamed, A.R. (2007). Humor in teaching. Kuala Lumpur: PTS Profesional Publishing Sdn. Bhd.

Ahmad, A., \& Jinggan, N. (2015). The effect of teachers' competency in teaching on academic achievement in history. Journal of Asia Pacific Curriculum and Teaching, 3(2), 1-11.

Amran, S., Rahman, S., \& Surat, S. (2017). Positive emotions of effective learning: From the perspective og neuroscience into the classroom. VIII Regional Education Seminar at National University of Malaysia.

Bakar, F., \& Kumar, V. (2019). The use of humour in teaching and learning in higher education classrooms: Lecturers' perspective. Journal of English for Academic Purposes, 40, 15-25.

Bhattacharyya, E., \& Sarip, A.M. (2014). Learning style and its impact in higher education and human capital needs. Procedia Social and Behavioral Sciences, 123, 485-494. 
Gholami, S., \& Bagheri, M.S. (2013). Relationship between VAK learning styles and problem solving styles regarding gender and students field of study. Journal of Language Teaching and Research, 4(4), 700-706.

Gilliam, L.M. (2019). Magical management in the classroom: Using humor to speak their language. New York: Rowman \& Littlefield Publishing Group.

Jihene, M., Rejeb, R.B., \& Malefan, P.L. (2020). The role of humor in sustainable educational and innovation. Journal of Sustainable Developmental and Social Responsibility, 2, 361-371.

Junis, C.R., \& Sintian, M. (2019). Elements of humor in Kadazandusun language teaching: An introduction. Tanjong Malim: Publisher of Sultan Idris Education University.

Mahamod, Z., Ghani, K.A., \& Mohamad, W.M.R.W. (2016). The use of Malay language learning strategic among students in China based on the attitude and language skills. Journal of Malay Educational, 6(1), 38-51.

Pourhossein, A. (2012). Visual, auditory, kinesthetic learning styles and their impacts on English language teaching. Journal of Studies in Education, 2(1), 104-113.

Reduwan, N.H. (2011). The elements of humor as a stimulant in the Malay language learning among Malay students at Sultan Idris Education University. Serdang: University Putra Malaysia.

Reduwan, N.H., Yusuf, R.Y., \& Hasim, H. (2016). Application Model VAK in the style of teaching and learning of Malay language Literature Components. E-Proceeding of the Regional Conference on Civilization and Islamic Thoughts. Australia.

Reid. J. (1984). Perceptual learning style preference questionnaire. Laramie: University of Wyoming.

Sukor, M.S.M., \& Shah, I.M. (2016). Behavioral humor among postgraduate faculty of management. Journal of Humanities, 25(3), 74-86. 